\title{
DETECTION OF CFTR MUTATIONS IN CHILDREN WITH CYSTIC FIBROSIS
}

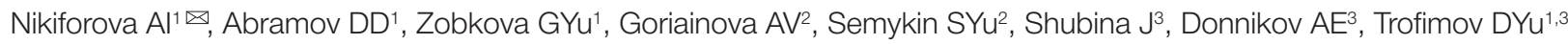 \\ ${ }^{1}$ DNA-Technology LLC, Moscow \\ ${ }^{2}$ Russian Children's Clinical Hospital, Pirogov Russian National Medical Research University, Moscow \\ ${ }^{3}$ Laboratiry of Molecular Genetics, Kulakov National Medical Research Center of Obstetrics, \\ Gynecology and Perinatology, Moscow
}

Cystic fibrosis (CF) is one of the most common monogenic disorders of humans. The knowledge of population frequency of a mutant genotype causing a monogenic disease helps to optimize DNA testing and to reduce its costs and time required for the procedure. This article presents the results of a retrospective study of the CFTR gene in 191 children with mixed manifestations of CF. To screen for 24 most common mutations, we used the diagnostic PCR panel; minor mutations were detected by next generation sequencing. The diagnostic panel allowed us to identify 18 typical CFTR mutations, including F508del (allelic frequency of 54.7\%), dele 2,3 (21kb) (7.3\%), 2143delT (3.4\%), 2184insA (3.4\%), 1677delTA (2.4\%), N1303K (2.1\%), 3849+10kbC>T (2.1\%), E92K (2.1\%), G542X (1.6\%), W1282X (1.6\%), S1196X (1.3\%), R334W (1.0\%), 394delTT(0.8\%), 3944delGT (0.8\%), 3821 delT (0.5\%), 2789+5G>A (0.5\%), 621+1G>T(0.3\%), and 2183AA>G (0.3\%). Sequencing revealed the presence of 24 potentially pathogenic CFTR variants in the sample. We also discovered 8 minor CFTR variants previously unseen in Russian patients with CF, including 4 new CFTR mutations: p.Glu819Ter, p.Gln378Ter, p.Val1360Phefs, and p.Lys1365Argfs.

Keywords: cystic fibrosis, CFTR, CFTR mutations, Russian population

Conflict of interests: the study was conducted in collaboration with DNA-Technology staff.

$\triangle$ Correspondence should be addressed: Alena I. Nikiforova

Kashirskoe shosse 24, Moscow, 115478; nikiforova@dna-technology.ru

Received: 10.07.2018 Accepted: 03.08.2018

DOI: $10.24075 /$ brsmu.2018.037

\section{ОПРЕДЕЛЕНИЕ МУТАЦИЙ ГЕНА СFТRУ ДЕТЕЙ С МУКОВИСЦИДОЗОМ}

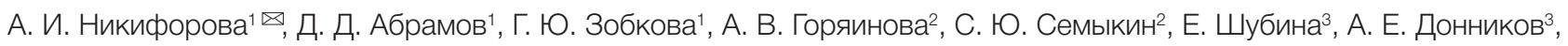 \\ Д. Ю. Трофимов ${ }^{1,3}$ \\ ${ }^{1} \mathrm{OОО}$ «НПФ ДНК-Технология», Москва \\ ${ }^{2}$ Российская детская клиническая больница Российского научно-исследовательского университета имени Н. И. Пирогова, Москва \\ ${ }^{3}$ Лаборатория молекулярно-генетических методов, Национальный медицинский исследовательский центр акушерства, гинекологии и перинатологии \\ имени В. И. Кулакова, Москва
}

\begin{abstract}
Муковисцидоз (МВ) - одно из наиболее распространенных моногенных заболеваний человека. Определение частоты мутаций моногенного заболевания для конкретных популяций позволяет оптимизировать ДНК-диагностику, сократив ее себестоимость и время проведения. В статье представлены результаты ретроспективного исследования гена CFTR у 191 ребенка со смешенной формой МВ. Для определения 24 наиболее распространенных мутаций CFTR использовали диагностическую ПЦР-панель, а минорные варианты выявляли методом высокопроизводительного секвенирования. C помощью диагностической панели в выборке выявлено 18 типичных мутаций гена CFTR: F508del (с аллельной частотой 54,7\%), dele 2,3 (21kb) (7,3\%), 2143delT (3,4\%), 2184insA (3,4\%), 1677delTA (2,4\%), N1303K (2,1\%), 3849+10kbC>T (2,1\%), E92K (2,1\%), G542X (1,6\%), W1282X (1,6\%), S1196X (1,3\%), R334W (1,0\%), 394delTT(0,8\%), 3944delGT (0,8\%), 3821 delT (0,5\%), 2789+5G>A (0,5\%), 621+1G>T(0,3\%), 2183AA>G (0,3\%). В результате секвенирования обнаружено 24 генетических варианта CFTR с потенциальной клинической значимостью. Обнаружено 8 минорных вариантов CFTR, до этого не отмеченных у пациентов в РФ, в том числе 4 новых мутации гена CFTR - p.Glu819Ter, p.GIn378Ter, p.Val1360Phefs и p.Lys1365Argfs.
\end{abstract}

Ключевые слова: муковисцидоз, CFTR, мутации CFTR, российская популяция больных муковисцидозом

Конфликт интересов: исследование проведено при участии сотрудников компании ДНК-Технология.

$\triangle$ Для корреспонденции: Никифорова Алёна Игоревна

Каширское ш., д. 24, г. Москва, 115478; nikiforova@dna-technology.ru

Статья получена: 10.07.2018 Статья принята к печати: 03.08.2018

DOI: $10.24075 /$ vrgmu.2018.037

Cystic fibrosis (CF) is a hereditary autosomal recessive disease that affects all exocrine glands, leading to severe impairment of the respiratory and digestive systems. CF is caused by deleterious mutations in the CFTR gene (CFTR stands for cystic fibrosis transmembrane conductance regulator) [1], most commonly by F508del (rs113993960) which results in the deletion of phenylalanine at position 508 in the protein
[1-3]. There is no known cure for CF; complex care should be provided for patients with CF throughout their lifetime.

$\mathrm{CF}$ is one of the most common hereditary diseases. According to the World Health Organization, the disease occurs in 1 in 2,500-3,000 newborns [3]. The Russian Cystic Fibrosis Patient Registry reported 2,916 new cases of CF in 2015 [4]. In 2016 the incidence of the disease among Russian neonates was $1: 8,788$ [5]. 
It is crucial to recognize CF before it is clinically manifested; timely diagnosis reduces the risk of irreversible damage to the respiratory and digestive systems and improves the quality of life of patients and their families [6].

Neonatal screening for CF adopted by the Russian Federation in 2006 is an important tool for early diagnosis. It comprises a series of diagnostic tests run consecutively, including the immunoreactive trypsinogen (IRT) blood test, the IRT repeat test, and the sweat chloride test ordered if IRT levels are elevated above the normal range [7].

Molecular genetic (or DNA) screening for mutations in the CFTR gene is conducted in several steps. The first step includes screening for the most common mutations using special diagnostic panels $[3,7,8]$. If this test comes out negative, the whole gene is sequenced $[3,9]$ and a search is performed for large structural CFTR variations, if necessary [3].

In Russia, genetic screening is not mandatory and is normally recommended if the sweat test cannot be done or its results are inconclusive. However, the CFTR genotype is one of the factors predicting the severity of the disease [3]; once it has been established, the doctor can come up with an adequate pharmacogenetic treatment plan [2, 3]. One of the advantages of DNA testing is its accuracy: unlike the sweat test, it is not affected by the physiology of an individual patient.

At present, there is a need for better availability of genetic screening in the Russian Federation. Even so, in the recent years extensive genetic epidemiology data on cystic fibrosis have been collected in Russia. The most common CFTR mutations have been identified [3, 8], and genetic variations associated with the disease in different ethnic groups have been described, as well as regional variations in the frequency of pathogenic alleles $[8,10,11]$. A good example here is the E92K (rs121908751) mutation typically found in the Chuvash people. A record of CFTR mutations has been kept by the Russian Cystic Fibrosis Patient Registry since 2011 [12]. A new registry of CFTR allelic variants has been created as part of the open-source international database of genetic variations LOVD v.3.0 (Leiden Open Variation Database). The registry is called SeqDB-LOVD/ Consensus view on the clinical effects of genetic variants and lists CFTR allelic variants occurring in the Russian population [13]. SeqDB-LOVD provides information on the clinical relevance of CFTR variants, including rare ones that were identified only due to the active use of NGS in research studies.

According to SeqDB-LOVD, there are currently over 220 clinically relevant CFTR mutations occurring in the Russian population; interestingly, new, previously unknown allelic variants come from relatively small samples [9]. With that in mind, one can safely assume that the real diversity of pathogenic CFTR mutations is much vaster.

About 500 children are annually referred to the Pediatric Unit of Children's Clinical Hospital (Pirogov Russian National Medical Research University) from different regions of Russia; of them about 100 are diagnosed with CF. Between 2014 and 2017, the Pediatric Unit admitted over 200 children with clinical signs of CF whose genotype was either unknown (no molecular genetic tests had been performed) or partially known (only one known CFTR mutation had been identified). The aim of this work was to determine the spectrum of pathogenic CFTR variants in the sample of 191 patients with severe CF with mixed clinical manifestations.

\section{METHODS}

For this retrospective study we selected blood samples collected from 191 children with severe or moderately severe cystic fibrosis referred to the Children's Clinical Hospital of Pirogov Russian National Medical Research University between 2014 and early 2017. In most cases, no genetic screening had been done to confirm the diagnosis. The main group consisted of boys and girls from 57 Russian regions (Moscow and Stavropol regions were represented by 15 patients each; other regions, by 1 to 9 patients each). The study included patients with clinically established diagnosis of severe CF with mixed manifestations (E 84.8). Patients with clinically established CF with predominantly pulmonary manifestations (E 84.0) or with mild or borderline symptoms were excluded from the study. The sample mainly consisted of unrelated patients; there were also 4 pairs of siblings. The study was approved by the Ethics Committee of Pirogov University (Protocol 172 dated February 2, 2018).

Peripheral blood samples were collected at the facilities of the Children's Clinical Hospital. Genomic DNA was isolated from the whole blood specimens stored in the Biobank of Kulakov National Medical Research Center of Obstetrics, Gynecology and Perinatology using the reagent kit Proba-GS-Genetika (DNA-Technology, Russia) according to the manufacturer's instructions.

Screening for the most common CFTR mutations was carried out using the following reagent kits: Genetics of hereditary diseases. Cystic fibrosis screen and Genetics of hereditary diseases. Cystic fibrosis: rare mutations (DNA-Technology, Russia). These reagent kits can detect 8 (F508del, dele 2,3 (21kb), 2143delT, 1677delTA, N1303K, 3849+10kbC>T, E92K, W1282X) and 16 (2184insA G542X, S1196X, R334W, 394delTT, 3944delGT, 3821delT, 2789+5G>A, 621+1G>T, 2183AA>G, L138ins, R117H, 604insA, 3667insTCAA, R553X, K598ins) allelic variants of the CFTR gene, respectively (here and below mutations included in the panels are listed by their common names). Detection relies on the use of kissing probes [14] and involves PCR amplification of the target gene region, hybridization of sequence-specific probes to amplification products, and recording of melting curves for the probes during their thermal denaturation (Fig. 1) [15, 16]. PCR was performed in the DTprime real-time detection cycler (DNA-Technology, Russia); probe melting temperatures were determined using the same device.

Screening for rare and unknown mutant variants of CFTR was done on the lon Torrent ${ }^{\mathrm{TM}}$ next generation sequencing platform (Thermo Fisher Scientific, USA). We targeted a number of coding regions (27 exons of CFTR), intron-exon boundaries and the promoter region. Additionally, the panel included a fragment for the identification of the pathogenic intron variant $3849+10 \mathrm{kbC}>\mathrm{T}$ (rs75039782) and the regions flanking the dele2,3(21 kb) mutation, a common deletion of exons 2 and 3 in the CFTR genes (Table 1).

Before sequencing, the targets were enriched by PCR, for which we used at least $10 \mathrm{ng}$ of the input genomic DNA amount. The PCR products were ligated to the adapters by T4 DNA ligase (Thermo Fisher Scientific, USA) according to the manufacturer's protocol. The quality of the prepared DNA libraries was assessed using the Agilent 2100 Bioanalyzer and the Agilent High Sensitivity DNA Kit (Agilent Technologies, USA). Next generation sequencing was carried out using the lon PGM Next-Generation Sequencing Systems (Ion Torrent ${ }^{\mathrm{TM}}{ }^{\mathrm{M}}$, USA) and the Ion PGM ${ }^{\mathrm{TM}}$ Template OT2 $400 \mathrm{Kit}^{\text {(Ion Torrent }}{ }^{\mathrm{TM}}$, USA) in the Laboratory of Molecular Genetics of Kulakov National Medical Research Center of Obstetrics, Gynecology and Perinatology.

Primary data analysis was assisted by the Torrent server 4.4.3. The obtained sequences were aligned to the reference genome GRCh37/hg19 by the TMAP tool; the reference 
genome included a fragment corresponding to the fusion amplicon marking the beginning of CFTRdele 2,3 (21 kb). Torrent Variant Caller 5.4.0.46 was used for variant calling. Further analysis was done by means of the original software developed by the authors of this work. The targeted regions were covered by an average of 4,500 reads; the minimum number of reads was 500 . To assess pathogenicity of variants, we consulted a few databases, including dbSNP Build 147, locus-specific CFTR1 [17], CFTR2 [18], and SeqDB-LOVD [13], as well as the literature sources. The results were validated by Sanger sequencing (of both DNA chains) on the ABI 3130 DNA Analyzer (Applied Biosystems, USA) using the original reagents according to the manufacturer's protocol. Sanger sequencing confirmed all obtained genotypes.

\section{RESULTS}

PCR-based genotyping detected 18 mutant variants of the CFTR gene in the studied sample of patients (Table 2). Homozygous variants were represented by F508del (70 patients), E92K, 1677delTA and dele 2,3 (21kb) detected in 3 patients each, and by W1282X (1 patient). One hundred forty-four patients (75.4\%) were found to have two pathogenic CFTR mutations, 41 patients $(21.5 \%)$ had only 1 mutation; for 6 patients $(3.1 \%)$ the screening was negative. Two pathogenic alleles present in the total of 112 patients (58.6\%) were detected using the panel of 8 common CFTR mutations described in Methods.

Mutations included in the panel were unambiguously identified or were shown to be absent in $99 \%$ of cases. In two samples (1\%) the melting curves recorded for one of the mutant gene variants looked abnormal. Direct sequencing of these samples revealed the presence of "off-target" single nucleotide polymorphisms in the regions hybridized to the allele-specific probes (Fig. 1). Forty-seven PCR-sequenced samples reported to be free of CFTR mutations were additionally sequenced by NGS. In total, 300 different genotypes were identified by sequencing, of which 24 could be clinically relevant (we accounted for the variants described in locus-specific databases as pathogenic, nonsense, or frameshift mutations) (Table 2). Some genotypes were observed more than once, such as p.Ser466Ter (rs121908805), which occurred as part of the compound allele in 5 unrelated patients (Table 3).

Of all detected mutations, 4 had not been described previously, including two frameshifts (c.4093delA/p.Lys1365Argfs and c.4078delG/p.Val1360Phefs) and two nonsense mutations (c.1132C>T/p.Gln378Ter and c.2455G>T/p.Glu819Ter) with a pathogenic potential (Table 4). These previously unknown variants were heterozygous and occurred in combination with the most frequent CFTR mutation (Table 3). We submitted these mutations to SeqDB-LOVD.

During Sanger validation, a deletion was detected in two samples in exon 24 resulting in the frameshift p.lle1214Phefs (rs397508630).

Our extensive DNA testing revealed that 178 patients from the sample had 2 pathogenic mutations and 13 patients had 1 pathogenic mutation. Notably, F508del (rs113993960), the most common mutation observed in the Russian population, was detected in 139 patients from 49 regions of the Russian
A

FAM fluorophore

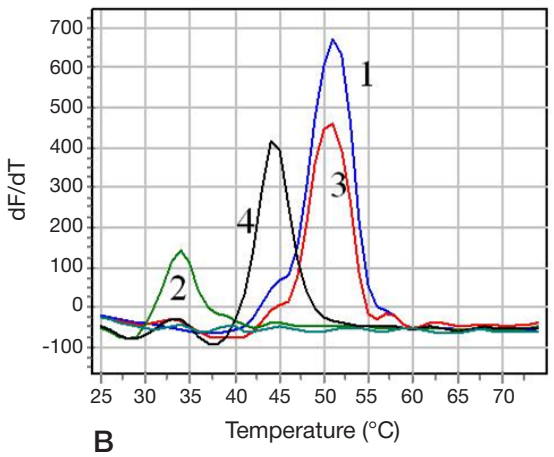

HEX fluorophore

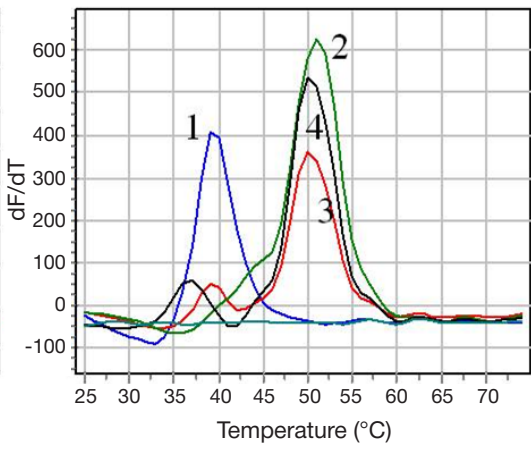

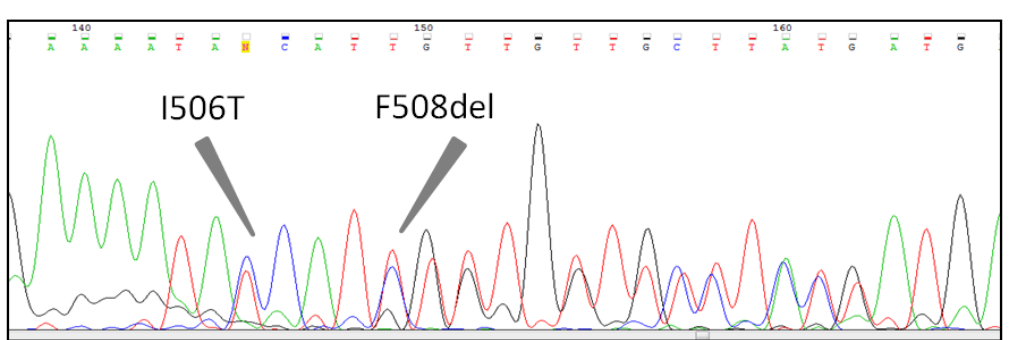

Fig. 1. A. Melting curves for different genotypes recorded during F508del (rs113993960) detection and an example of a combination of F508del and I506T (rs397508224) in the genotype. Fluorescence from FAM/HEX channels indicates the melting of probes complementary to a non-mutant or mutant gene region, respectively. The melting dynamics is recorded in the range from $25^{\circ} \mathrm{C}$ to $75^{\circ} \mathrm{C}$ and varies for different genotypes. $1-$ mutation is absent; 2 - homozygous mutation; 3 - heterozygous mutation; 4 - a combination of F508del and I506T (the peak of the melting curves deviates from the norm) B. The sequencing chromatogram of a DNA fragment with a combination of F508del and I506T

Table 1. Primer sequences for the amplification of regions including the boundaries of CFTRdele 2,3 (21 kb)

\begin{tabular}{|c|c|}
\hline Primer & Sequence \\
\hline del2,3F1 & tcc ctt ggt aaa att aag cct cat g \\
\hline del2,3R1 & ccc tcc tct gat tcc aca agg tat \\
\hline del2,3F2 & ccc aaa aac tat tgt cag act ctg ct \\
\hline del2,3R2 & cac cta cac tca gaa ccc atc ata gg \\
\hline
\end{tabular}


Federation. Four unrelated patients from Ingushetia and Chechnya were found to have 1677delTA (rs121908776). Three of 4 Chuvash patients had a homozygous E92K.

The proportion of patients with 2 "severe" (class I-III) CFTR mutations [19] was $69.6 \%$. The proportion of patients with one or two "mild" (class IV-V) mutations [19] was 8.4\%. Patients with one or two mutations of «uncertain clinical relevance» made up $22 \%$.

\section{DISCUSSION}

We have detected 36 different pathogenic variants of the CFTR gene in the studied group of patients. The majority of these mutations are known to be common in the Russian population [4, 8]. F508del (rs113993960) prevailed in the studied sample taken as a whole, as well as in the separate subgroups of patients coming from the regions dominated by Russians. The frequency of other mutations in the sample was consistent with the reports of CF in the Russian population [4, 8]. Ten mutations with the highest frequency in the sample are listed in the Russian CF Patient Registry [4]. The 1677delTA (rs121908776) mutation was the most common in children from the North Caucasus. Children from Chuvashia had the E92K (rs121908751) mutation typically associated with their ethnicity. The obtained results suggest that the study sample is representative of the Russian population afflicted with cystic fibrosis. Genotyping data obtained from the studied sample provide new information about the genetic diversity of cystic fibrosis in Russia.

Using different sequencing techniques, we detected 24 clinically relevant mutations of the CFTR gene (including 22 minor variants); of them 8 had not been previously reported by the Russian CF Patient Registry, including p.Gln39Ter (rs397508168), p.Phe1286Ser (rs121909028), p.lle1214Phefs (rs397508630), p.Trp1063Terfs, p.Glu819Ter, p.GIn378Ter, p.Val1360Phefs, and p.Lys1365Argfs. According to in silico prediction tools, these mutations are pathogenic (belong to class I) and result in the truncated CFTR protein.

PCR-based sequencing demonstrated a detection rate of $86.1 \%$ for deleterious CFTR mutations (in $98.9 \%$ of cases one or two pathogenic variants were detected). This value meets the requirements for diagnostic panels [19]. However, considering the huge array of genetic epidemiology data obtained in the recent years $[4,13]$ and the results of additional diagnostic testing we performed on the samples, we believe that the detection rate can be improved by including p.Ser466Ter (rs121908805), p.Trp1282Arg (rs397508616) and p.Leu15Phefs (rs397508715) mutations into the panel. The PCR-based kissing-probe method that we used to screen for known CFTR mutations has a few advantages over alternative approaches, such as MLPA or RFLP): all stages of the procedure including the analysis of melting curves take place in one device, and electrophoresis is not required. The results are interpreted automatically. At the same time, visual control of the melting curves is possible, facilitating detection of polymorphisms located close to the targeted mutation. Considering its relative simplicity, good optimization potential (the method can be adjusted for PCR multiplexing, and the number of testing tubes with individual samples can be cut down) and automatic control of the procedure, this method can be used for high throughput sequencing/screening for common hereditary diseases.

The detection rate of extensive sequencing-based DNA testing was $95.4 \%$ (at least one pathogenic mutation was detected in each case). Detection rates may have been affected by the limitations of the NGS technology; as a rule, panels and analytical algorithms are optimized for better screening results [20]. Ion Torrent cannot reliably detect mutations inside homopolymer regions, such as 2184insA (rs121908786). In our study, the adenine deletion inside the region TATTT[A-] TIIITCT (mutation p.lle1214Phefs (rs397508630)) was detected only after the fragment was Sanger-sequenced. Lengthy deletions and duplications also pose a problem for Ion Torrent, as recognition of their heterozygous genotypes requires specific bioinformatic algorithms of data processing; long deletions require incorporation of additional targets into the panel to cover their boundaries [9] or even a series of additional targets corresponding to the most frequent genotypes observed in a population. So far, residents of the Russian Federation with CF have been shown to have a few lengthy deletions, of which CFTRdele 2,3 is the most common

Table 2. Results of PCR genotyping in 191 patients with cystic fibrosis

\begin{tabular}{|c|c|c|}
\hline Mutation & RefSNP (rs) & Allelic frequency (\%) \\
\hline F508del & rs113993960 & 54.7 \\
\hline dele $2.3(21 \mathrm{~kb})$ & - & 7.3 \\
\hline 2143delT & rs121908812 & 3.4 \\
\hline 2184insA & rs121908786 & 3.4 \\
\hline 1677delTA & rs121908776 & 2.4 \\
\hline N1303K & rs80034486 & 2.1 \\
\hline $3849+10 \mathrm{~kb} C>T$ & rs75039782 & 2.1 \\
\hline E92K & rs121908751 & 2.1 \\
\hline G542X & rs113993959 & 1.6 \\
\hline W1282X & rs77010898 & 1.6 \\
\hline S1196X & rs121908763 & 1.3 \\
\hline $\mathrm{R} 334 \mathrm{~W}$ & rs121909011 & 1.0 \\
\hline 394delTT & rs121908769 & 0.8 \\
\hline 3944delGT & rs397508612 & 0.8 \\
\hline 3821delT & rs77035409 & 0.5 \\
\hline $2789+5 G>A$ & rs 80224560 & 0.5 \\
\hline $621+1 G>T$ & rs78756941 & 0.3 \\
\hline $2183 A A>G$ & rs121908799 & 0.3 \\
\hline
\end{tabular}




\section{ORIGINAL RESEARCH I MEDICAL GENETICS}

Table 3. Results of next generation sequencing of the CFTR gene in 47 patients

\begin{tabular}{|c|c|c|}
\hline ID & PCR data & Sequencing data \\
\hline 1 & dele $2,3(21 \mathrm{~kb}) /$ ? & dele 2,3 (21kb)/p.Asn415Terfs (rs397508184) \\
\hline 2 & $3849+10 \mathrm{kbC}>\mathrm{T} / ?$ & $3849+10 \mathrm{kbC}>\mathrm{T} / \mathrm{Tyr} 84 \mathrm{Ter}(\mathrm{rs}-)$ \\
\hline 3 & F508del/? & F508del/p.lle1214Phefs (rs397508630) * \\
\hline 4 & F508del/? & F508del/p.Arg1070Gln (rs78769542) \\
\hline 5 & $? / ?$ & [p.Ser466Ter; p. Arg1070GIn] ( rs121908805; rs78769542)/? \\
\hline 6 & $? / ?$ & p.Arg1066Cys(rs78194216)/ p.Arg1066Cys (rs78194216) \\
\hline 7 & 1677delTA/? (E92K) & 1677delTA/p.Ala96Glu (rs397508449) \\
\hline 8 & $? / ?$ & c.1766+1G>C (rs121908748)/p.Gly314Arg (rs397508819) \\
\hline 9 & $? / ?$ & c. $580-1 \mathrm{G}>\mathrm{T}(\mathrm{rs} 121908748) / \mathrm{c} .1766+2 \mathrm{~T}>\mathrm{C}(\mathrm{rs}-)$ \\
\hline 10 & ? (F508del)/? & F508del/p.lle506Thr (rs397508224) \\
\hline 11 & $? / ?$ & p.GIn39Ter (rs397508168)/p.Arg785Ter (rs374946172) \\
\hline 12 & F508del/? & F508del/? \\
\hline 13 & $\mathrm{~N} 1303 \mathrm{~K} / ?$ & N1303K/p.Asn415Terfs (rs397508184) \\
\hline 14 & F508del/? & F508del/? \\
\hline 15 & F508del/? & F508del/p.Arg347Pro (rs77932196) \\
\hline 16 & F508del/? & F508del/p.Leu15Phefs (rs397508715) \\
\hline 17 & 3944delGT/? & 3944delGT/p.Phe1286Ser (rs121909028) \\
\hline 18 & $\mathrm{~S} 1196 \mathrm{X} / ?$ & S1196X/p.Leu15Phefs (rs397508715) \\
\hline 19 & F508del/? & F508del/p.Glu1418Argfs (rs397508706) \\
\hline 20 & F508del/? & F508del/p.Arg1066Cys (rs78194216) \\
\hline 21 & F508del/? & F508del/p.Glu819Ter (rs-)* \\
\hline 22 & F508del/? & F508del/c.3140-16T>A (rs767232138) \\
\hline 23 & F508del/? & F508del/? \\
\hline 24 & F508del/? & F508del/p.Trp1282Arg (rs397508616) \\
\hline 25 & F508del/? & F508del/p.Gln378Ter (rs-)* \\
\hline 26 & dele 2,3 $(21 \mathrm{~kb}) /$ ? & dele 2,3 (21kb)/p.Glu217Gly, p.Arg153Lys (rs121909046, rs149197463) \\
\hline 27 & W1282X/? & W1282X/p.Gly1047Ser (rs397508504) \\
\hline 28 & $\mathrm{~S} 1196 \mathrm{X} / ?$ & S1196X/p.Leu15Phefs (rs397508715) \\
\hline 29 & 2143delT/? & 2143delT/ [p.Ser466Ter; p.Arg1070Gln] (rs121908805; rs78769542) \\
\hline 30 & dele $2,3(21 \mathrm{~kb}) / ?$ & dele 2,3 (21kb)/p.Val1360Phefs (rs-) $)^{*}$ \\
\hline 31 & F508del/? & F508del/p.Trp1282Arg (rs397508616) \\
\hline 32 & F508del/? & F508del/p.Trp496Ter (rs200626971) \\
\hline 33 & 3944delGT/? & 3944delGT/? \\
\hline 34 & $\mathrm{~N} 1303 \mathrm{~K} / ?$ & N1303K/p.Lys1177Serfs (rs121908747) \\
\hline 35 & F508del/? & F508del/? \\
\hline 36 & G542X/? & G542X/p.Ser466Ter;p.Arg1070GIn] (rs121908805; rs78769542) \\
\hline 37 & F508del/? & F508del/p.Lys1365Argfs (rs-)* \\
\hline 38 & dele $2,3(21 \mathrm{~kb}) / ?$ & dele 2,3 (21kb)/p.lle1214Phefs (rs397508630) ** \\
\hline 39 & 2143delT/? & 2143delT/[p.Ser466Ter; p.Arg1070Gln] (rs121908805; rs78769542) \\
\hline 40 & dele 2,3 (21kb) & dele 2,3 (21kb)/p.Arg785Ter (rs374946172) \\
\hline 41 & F508del/? & F508del/? \\
\hline 42 & $\mathrm{~W} 1282 \mathrm{X} / ?$ & $\mathrm{~W} 1282 \mathrm{X} / ?$ \\
\hline 43 & 394delTT/? & 394delTT/p.Trp1282Arg (rs397508616) \\
\hline 44 & $3849+10 \mathrm{kbC}>\mathrm{T} / ?$ & 3849+10kbC>T/[p.Ser466Ter; p.Arg1070Gln] (rs121908805; rs78769542) \\
\hline 45 & $2183 A A>G / ?$ & $2183 A A>G / ?$ \\
\hline 46 & F508del/? & F508del/p.Trp1310Ter (rs397508645) \\
\hline 47 & F508del/? & F508del/p.Trp1063Terfs (rs-) \\
\hline
\end{tabular}

Note: * — represents 4 previously undescribed CFTR mutations shown in bold; ${ }^{*}$ — represents p.lle1214Phefs (rs397508630) detected by Sanger sequencing; ? - means that candidate variants have not been identified. 
Table 4. Description of 4 newly discovered variants of CFTR and patients' phenotypes

\begin{tabular}{|c|c|c|c|}
\hline Patient ID & Sex & Phenotype & Description \\
\hline BRMVedZB99 & $\mathrm{F}$ & $\begin{array}{l}\text { Cystic fibrosis, mixed manifestations, severe course. } \\
\text { Chronic purulent obstructive bronchitis. } \\
\text { Chronic pancreatic insufficiency. Bronchiectasis. Liver cirrhosis }\end{array}$ & $\begin{array}{l}\text { NC_000007.14:g.117592622G }>\text { T; } \\
\text { NM_000492.3:c.2455G>T; } \\
\text { NP_000483.3:p.Glu819Ter }\end{array}$ \\
\hline BRMVedZB112 & $\mathrm{F}$ & $\begin{array}{l}\text { Cystic fibrosis, mixed manifestations, severe course. } \\
\text { Chronic pancreatic insufficiency. Bronchiectasis }\end{array}$ & $\begin{array}{l}\text { NC_000007.14:g.117542031C>T; } \\
\text { NM_000492.3:c.1132C>T; } \\
\text { NP_000483.3:p.Gln378Ter }\end{array}$ \\
\hline BRMVedZB138 & M & $\begin{array}{l}\text { Cystic fibrosis, mixed manifestations, severe course. } \\
\text { Chronic purulent obstructive bronchitis. Chronic pancreatic insufficiency. } \\
\text { Chronic rhinosinusitis with nasal polyps }\end{array}$ & $\begin{array}{l}\text { NC_000007.14:g.117664802delG; } \\
\text { NM_000492.3:c.4078delG; } \\
\text { NP_000483.3:p.Val1360Phefs } 20\end{array}$ \\
\hline BRMVedZB185 & M & $\begin{array}{l}\text { Cystic fibrosis, mixed manifestations, severe course. Chronic purulent } \\
\text { obstructive bronchitis. Chronic pancreatic insufficiency. Liver cirrhosis. } \\
\text { Chronic rhinosinusitis with nasal polyps }\end{array}$ & $\begin{array}{l}\text { NC_000007.14:g.117664818delA; } \\
\text { NM_000492.3:c.4094delA; } \\
\text { NP_000483.3:p.Lys1365Argfs15 }\end{array}$ \\
\hline
\end{tabular}

with a frequency of 1.4-8\% [8]. We managed to reliably identify the heterozygous carriers of CFTRdele 2,3 by NGS after adding a few extra pairs of primers specific to the boundaries of the deletion; in contrast, estimating the abundance of reads yielded by the sequencing of homozygous, heterozygous and normal variants of CFTRdele 2,3 turned to be unreliable.

\section{CONCLUSIONS}

According to the Russian Cystic Fibrosis Patient Registry, 30 to 35 mutations of the CFTR gene have an allelic frequency of $\leq 1 \%$; at the same time, common pathogenic variants make up about $20 \%$ of total allelic diversity. Molecular genetic screening of patients with CF can be enhanced by using combinations of different approaches, such as PCR-based detection of individual polymorphisms with subsequent next generation sequencing of negative samples. In the present study $86.1 \%$ of pathogenic CFTR variants were identified using the panel of 24 mutations associated with $\mathrm{CF}, 10 \%$ were identified by sequencing. We also detected 8 minor CFTR genotypes previously unseen in the residents of Russia, including 4 new pathogenic mutations: p.Glu819Ter, p.Gln378Ter, p.Val1360Phefs and p.Lys1365Argfs.

\section{References}

1. Kerem B, Rommens JM, Buchanan JA, Markiewicz D, Cox TK, Chakravarti $A$, et al. Identification of the cystic fibrosis gene: genetic analysis. Science. 1989 Sep 8; 245 (4922): 1073-80.

2. Dodge JA. A millennial view of cystic fibrosis. Dev Period Med. 2015 Jan-Mar; 19 (1): 9-13.

3. Baranov AA, Kapranov NI, Kashirskaya NY, et al. Diagnostic Problems of Mucoviscidosis and Ways of Solution in Russia. Pediatric pharmacology. 2014; 11 (6): 16-23.

4. Kondrateva El, Krasovskij SA, Voronkova AJu, Amelina EL, Cherniak AV, Kashirskaja N. Ju., redaktory. Registr bol'nyh mukoviscidozom v Rossijskoj Federacii. 2015 god. M.: ID MEDPRAKTIKA-M; 2016. $72 \mathrm{~s}$.

5. Sherman VD, Kondrat'eva El, Kashirskaja NJu, Kalinenkova SG, Kotalevskaja JuJu. Neonatal'nyj skrining na mukoviscidoz. Itogi 10 let. Vtoraja Vserossijskaja nauchno-prakticheskaja konferencija «Novye tehnologii diagnostiki nasledstvennyh boleznej» Moskva, 27-28 oktjabrja $2017 \mathrm{~g}$.

6. Kashirskaya NY, Krasovsky SA, Chernyak AV, Sherman VD, Voronkova AY, Shabalova LA, et al. Trends in Life Expectancy of Cystic Fibrosis Patients in Moscow and their Connection with the Treatment Received: Retrospective Analysis for 1993-2013 Current pediatrics. 2015; 14 (4): 503-8.

7. Sherman VD, Kashirskaja NJu, Kapranov NI. Sovremennyj algoritm diagnostiki mukoviscidoza. Pediatrija. 2014; 93 (4).

8. Stepanova AA, Krasovsky SA, and Polyakov AV. Reliability of the Search for 19 Common Mutations in the CFTR Gene in Russian Cystic Fibrosis Patients and the Calculated Frequency of the Disease in Russian Federation. Russian Journal of Genetics. 2016; 52 (2): 204-13.

9. Simakova TS, Bragin AG, Glushkova MA, Petrova NV, Polyakov AV, Kondratieva El, et al. The experience of application of target sequencing in molecular diagnostic of mucoviscidosis. Klinicheskaya Laboratornaya Diagnostika. 2017; 62 (5): 305-309.
10. Stepanova AA, Polyakov AV, Abrukova AV, Savaskina EN. Mutation p.E92K is the primary cause of cystic fibrosis in Chuvashes Russian Journal of Genetics. 2012; 48 (7): 731-7.

11. Petrova NV, Timkovskaya EE, Vasilyeva TA et al. Characteristics the spectrum of cftr mutations in Karachay-Cherkessia. Meditsinskaia genetika 2015; 14 (7): 32-6.

12. Krasovsky SA, Chernyak AV, Kashirskaya N.Yu. et al. Cystic fibrosis in Russia: the creation of a national register. Pediatrics. 2014; 93 (4).

13. Available from: http://segdb.med-gen.ru/

14. Kofiadi IA, Rebrikov DV. Methods for detecting single nucleotide polymorphisms: Allele-specific PCR and hybridization with oligonucleotide probe Russian Journal of Genetics. 2006; 42 (1): $16-26$.

15. Abramov DD, Kadochnikova W, Yakimova EG, Belousova MV, Maerle AV, Sergeev IV et al. High carrier frequency of CFTR gene mutations associated with cystic fibrosis, and PAH gene mutations associated with phenylketonuria in Russian population. Bulletin of RSMU. 2015; (4): 32-5.

16. Sergeev IV, Haitov MR, Trofimov DJu, Abramov DD, Grudakova EG, Goncharova EV, i dr. Razrabotka metodov dlja provedenija shirokomasshtabnyh issledovanij polimorfizma genov, regulirujushhih razlichnye komponenty immunnogo otveta. Fiziol i patol immun sistemy. 2009; 13 (4): 21-6.

17. Available from: http://www.genet.sickkids.on.ca

18. Available from: https://www.cftr2.org/

19. Castellani C, Cuppens H, Macek M, et al. Consensus on the use and interpretation of cystic fibrosis mutation analysis in clinical practice. J Cyst Fibros. 2008 May; 7 (3): 179-96.

20. Shin S, Kim Y, Chul Oh S, Yu N, Lee ST, Rak Choi J, et al.Validation and optimization of the lon Torrent $\mathrm{S} 5 \mathrm{XL}$ sequencer and Oncomine workflow for BRCA1 and BRCA2 genetic testing. Oncotarget. 2017 May 23; 8 (21): 34858-66.

\section{Литература}

1. Kerem B, Rommens JM, Buchanan JA, Markiewicz D, Cox TK, Chakravarti $A$, et al. Identification of the cystic fibrosis gene:

genetic analysis. Science. 1989 Sep 8; 245 (4922): 1073-80. 2. Dodge JA. A millennial view of cystic fibrosis. Dev Period Med. 
2015 Jan-Mar; 19 (1): 9-13.

3. Баранов А. А., Капранов Н. И., Каширская Н. Ю. и др. Проблемы диагностики муковисцидоза и пути их решения в России. Педиатрическая фармакология. 2014; 11 (6): 16-23.

4. Кондратьева Е. И., Красовский С. А., Воронкова А. Ю., Амелина Е. Л., Черняк А. В., Каширская Н. Ю., редакторы. Регистр больных муковисцидозом в Российской Федерации. 2015 год. М.: ИД МЕДПРАКТИКА-М; 2016. 72 с.

5. Шерман В. Д., Кондратьева Е. И., Каширская Н. Ю., Калиненкова С. Г., Коталевская Ю. Ю. Неонатальный скрининг на муковисцидоз. Итоги 10 лет. Вторая Всероссийская научно-практическая конференция «Новые технологии диагностики наследственных болезней» Москва, 27-28 октября 2017 г.

6. Каширская Н. Ю., Красовский С. А., Черняк А. В. и др. Динамика продолжительности жизни больных муковисцидозом, проживающих в Москве, и ее связь с получаемой терапией: ретроспективный анализ за 1993-2013 гг. Вопросы современной педиатрии. 2015; 14 (4): 503-8.

7. Шерман В. Д., Каширская Н. Ю., Капранов Н. И. Современный алгоритм диагностики муковисцидоза. Педиатрия. 2014; 93 (4).

8. Степанова А. А., Красовский С. А., Поляков А. В. Инфоормативность поиска 19 частых мутаций в гене CFTR у российских больных муковисцидозом и расчетная частота заболевания в Российской популяции. Генетика. 2015; 52 (2): 231-41.

9. Симакова Т. С., Брагин А. Г., Глушкова М. А., Петрова Н. В., Поляков А. В., Кондратьева Е.И., и др. Опыт применения таргетного секвенирования для молекулярной диагностики муковисцидоза. Клиническая лабораторная диагностика. 2017; 62 (5): 305-9.

10. Степанова А. А., Абрукова А. В., Саваскина Е. Н., Поляков А. В. Мутация р.Е92K -основная причина муковисцидоза у чувашей. Генетика. 2012; 48 (7): 863-71.
11. Петрова Н. В., Тимковская Е. Е., Васильева Т. А. и др. Особенности спектра мутаций в гене CFTR у больных муковисцидозом из Карачаево-Черкесии. Медицинская генетика. 2015; 14 (7): 32-6.

12. Красовский С. А., Черняк А. В., Каширская Н. Ю. и др. Муковисцидоз в России: создание национального регистра. Педиатрия. 2014; 93 (4).

13. Доступно по ссылке: http://seqdb.med-gen.ru/

14. Косриади И. А., Ребриков Д. В. Методы детекции однонуклеотидных полиморфизмов: аллель-специфичная ПЦР и гибридизация с олигонуклеотидной пробой. Генетика 2006; 42 (1): 22-32.

15. Абрамов Д. Д., Кадочникова В. В., Якимова Е. Г., Белоусова М. В., Маерле А. В., Сергеев И. В. и др. Высокая частота носительства в российской популяции мутаций гена CFTR, ассоциированных с муковисцидозом, и мутаций гена РАН, ассоциированных с фенилкетонурией. Вестн. РГМУ. 2015; (4): 32-5.

16. Сергеев И. В., Хаитов М. Р., Трофимов Д. Ю., Абрамов Д. Д., Грудакова Е. Г., Гончарова Е. В. и др. Разработка методов для проведения широкомасштабных исследований полиморфизма генов, регулирующих различные компоненты иммунного ответа. Физиол. и патол. иммун. системы. 2009; 13 (4): 21-6.

17. Доступно по ссылке: http://www.genet.sickkids.on.ca/cftr/app

18. Доступно по ссылке: https://www.cftr2.org/

19. Castellani $\mathrm{C}$, Cuppens $\mathrm{H}$, Macek M, Jr, et al. Consensus on the use and interpretation of cystic fibrosis mutation analysis in clinical practice. J Cyst Fibros. 2008 May; 7 (3): 179-96.

20. Shin S, Kim Y, Chul Oh S, Yu N, Lee ST, Rak Choi J, et al. Validation and optimization of the lon Torrent $S 5 \mathrm{XL}$ sequencer and Oncomine workflow for BRCA1 and BRCA2 genetic testing. Oncotarget. 2017 May 23; 8 (21): 34858-66. 